How to cite this article:

Alkan, M. F., Arslan, M. (2019). Learner autonomy of pre-service teachers and its associations with academic motivation and self-efficacy. Malaysian Journal of Learning and Instruction, 16(2), 75-96.

\title{
LEARNER AUTONOMY OF PRE-SERVICE TEACHERS AND ITS ASSOCIATIONS WITH ACADEMIC MOTIVATION AND SELF-EFFICACY
}

\author{
${ }^{1}$ Muhammet Fatih Alkan \& ${ }^{2}$ Mehmet Arslan \\ ${ }^{1}$ Department of Educational Sciences, Tokat Gaziosmanpasa \\ University, Turkey \\ ${ }^{2}$ Department of Primary School Teaching, Girne American \\ University, TRNC
}

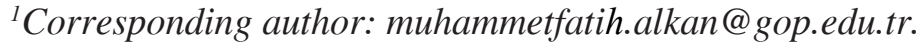

Received: 25/5/2018 $\quad$ Revised: 31/7/2019 Accepted: 24/9/2019 $\quad$ Published:24/12/19

\begin{abstract}
Purpose - Learner autonomy enables an individual to learn how to cope with novelties without seeking help from others. Considering the rapid changes and transformations of the $21^{\text {st }}$ century, it has become essential for teachers to possess this characteristic. Thus, their level of learner autonomy should be determined. The purpose of this two-phased study was to adapt the Autonomous Learning Scale into Turkish and to investigate academic motivation and selfefficacy as predictors of autonomous learning.

Methodology - In the first phase of the study, the Autonomous Learning Scale was adapted into Turkish with the participation of 335 pre-service teachers. In the second phase, a survey method was used to investigate the autonomous learning of 776 pre-service teachers in terms of a number of demographic variables, along with academic self-efficacy and academic motivation.
\end{abstract}

Findings - For the first phase, the confirmatory factor analysis showed that the Autonomous Learning Scale was a valid and 
reliable tool to be used with Turkish samples. For the second phase, regression analysis revealed that academic self-efficacy and academic motivation were significant predictors of autonomous learning among pre-service teachers. Additionally, their autonomous learning significantly differed in terms of department, high school type and gender. Furthermore, the GPAs of the pre-service teachers were significantly correlated with their autonomous learning levels.

Significance - The Turkish version of the Autonomous Learning Scale is presented to researchers. The relationships between autonomous learning and self-efficacy along with motivation have been asserted in a number of studies. The present study not only confirmed the correlations among these variables, but also revealed the predictive power of these variables on autonomous learning. Therefore, teacher educators and policy makers may gain insights from these findings.

Keywords: Autonomous learning, academic motivation, academic self-efficacy, pre-service teachers.

\section{INTRODUCTION}

Significant changes and transformations resulting from rapid and extensive developments in science and knowledge have occurred around the world, especially in the last quarter of the $20^{\text {th }}$ century (Kaplan, 2016). With this rapid increase in information and technology, basic elements of life such as transportation, professional life, communication and social media have varied considerably. As a result, individuals are now required to keep up with the changes (Medel-Anonuevo, 2002). At this point, learner autonomy distinguishes itself from other characteristics that individuals may possess because it enables the individual to learn how to cope with novelties without the help of others. The following detailed explanation of learner autonomy will substantiate this argument.

Autonomous learning can be defined as the ability to take charge of one's own learning (Holec, 1981). A similar definition was proposed by Benson (2001) who identified it as being control over learning. According to Mynard and Sorflaten (2003), autonomous learners are self-confident and aware of both their weak and strong sides, can 
make decisions about their learning, reflect their knowledge on real life situations, take charge of their learning, plan and set their targets, and assess their learning process and progress. Similarly, Oxford (2003) stated that autonomous learners possess characteristics such as high motivation, self-efficacy, sense of effectiveness, desire to seek meaning, positive attitude, the need to achieve, and a combination of internal and external motivation. The gist of learner autonomy is to make one's own decisions and take control of one's own learning. Consequently, it can be argued that it would be easier for individuals to keep up with the changing world if they possess these characteristics.

The literature in this area identifies self-efficacy or academic self-efficacy as one of the variables underlying learner autonomy (Flannagan, 2007; Macaskill \& Denovan, 2013; Mahmoudi \& Asadi, 2016; Nosratinia \& Hossaini, 2018; Overall, Deane, \& Peterson, 2011; Ponton, Derrick, Confessore, \& Rhea, 2005; Pu, 2009; T1lfarlığlu \& Çiftçi, 2011). Bandura (1997) defined self-efficacy as one's belief in one's ability to succeed in specific situations. The interaction between the renvironment and the individual plays an important role in the construction of self-efficacy. According to Bandura (1995), individuals are born without a sense of self. However, they develop their sense of self as they take actions on their environment and observe and interpret the effects of those actions. In other words, individuals develop their self-efficacy beliefs as they master certain skills and have a growing control over their environment no matter what their age is. Self-efficacy beliefs emphasize that they can create an effect on what they do (Bandura, 1997). Therefore, it is not abnormal to presume that the self-efficacy beliefs of individuals may be associated with their autonomous learning behaviours since self-efficacy beliefs underlie what they think, how they feel, how they make their choices and how they motivate themselves (Bandura, 1997). Furthermore, various studies have confirmed this relationship (Flannagan, 2007; Macaskill \& Denovan, 2013; Mahmoudi \& Asadi, 2016; Nosratinia \& Hossaini, 2018; Overall et al., 2011; Ponton et al., 2005; Pu, 2009; T1lfarlıŏglu \& Çiftçi, 2011). The statistical or theoretical results of these studies showed a strong relationship between learner autonomy and selfefficacy. Therefore, academic self-efficacy was included in this study as a possible predictor of autonomous learning. 
Motivation is another variable that is associated with autonomous learning. From the perspective of Self-determination theory, motivation is created as a result of meeting three psychological needs: autonomy, competence, and relatedness (Deci \& Ryan, 2008). Social contexts that meet these psychological needs provide an environment for individuals to grow and develop themselves (Deci \& Ryan, 1985). Autonomy, from this perspective, is defined as a phase where individuals believe that the activities concerned are started by themselves and not controlled by others (Deci \& Ryan, 2002). Theoretically, autonomy is argued to be associated with internal motivation (Niemiec \& Ryan, 2009), which is defined as conducting an activity in order to obtain internal satisfaction rather than an external reward (Ryan \& Deci, 2000). Chalupa and Haseborg (2014) found a strong positive correlation between individuals' autonomous learning choices and their motivation. Similarly, Spratt, Humphreys and Chan (2002) contend that motivation was a prerequisite for autonomy and that autonomous learning was restrained in the absence of motivation. Dickinson (1995) as well as Garcia and Pintrich (1996) were among the researchers who have demonstrated this association in their studies. Based on these results, academic motivation was assumed to be one of the factors that predicted autonomous learning.

Demographic variables are among the variables that have been researched in relation to autonomous learning. Certain demographic variables investigated within the scope of the current study as psychological concepts are theoretically associated with environmental factors (Bandura, 1995; 1997). Gender is one of these demographic variables. Razeq (2014) examined the autonomous learning of undergraduates within the context of learning English. He found a significant difference in the autonomous learning practices of participants in favour of female students. Similarly, Naeghel and Keer (2013) also found a significant difference in the autonomous reading motivation of primary school students in favour of female students. Parallel to these findings, Hanbay (2013) determined that female students had significantly higher autonomous learning levels within the context of learning German as a foreign language. Nevertheless, O'Reilly (2014) as well as Pan and Gauvain (2012) were unable to determine a significant difference in the autonomous 
learning levels of the participants in their studies. Based on past findings, gender was chosen as a variable in the present study.

Age is another demographic variable. O'Reilly (2014) found no significant relationship between age and perceived autonomy support. Similarly, Ng and Confessore (2015) were unable to determine a significant relationship between age and learner autonomy. Age and grade level were investigated in the present study. The participants' residential location, the geographical regions that they were from, the type of high school from which they graduated, and their family income were also investigated. The justification for including these variables was the possibility of environmental impact on psychological constructs. The pre-service teachers' department was another variable studied. Pan and Gauvain (2012) found that the autonomous learning motivation scores of their participants did not differ significantly in terms of their departments. The final variable in the present study was participant's grade point average (GPA). The literature has established a relationship between academic achievement and autonomous learning levels (Liu, 2007; Lowe, 2009; Ng, Confessore, Yusoff, Aziz, \& Lajis, 2011). Deregözü and Hatipoğlu (2018) found that although the autonomous learning scores of pre-service German teachers did not differ in terms of grade level and educational background, there were statistical differences with regards to age and gender. These demographic variables were included in the current study to further establish their relationships with autonomous learning,

In addition to investigating the potential relationships between learner autonomy and particular demographic variables, academic self-efficacy and academic motivation were examined as potential predictors of learner autonomy among pre-service teachers. The study was conducted in two phases. The first phase involved the adaptation of the 'Autonomous Learning Scale' into Turkish. The second phase aimed at exploring the autonomous learning of preservice teachers in relation to certain demographic variables, and with their academic motivation and self-efficacy as its predictors.

\section{METHODOLOGY}

This study employed a survey research design to determine the relationships among learner autonomy, academic self-efficacy and 
academic motivation. In surveys, the data are gathered at a particular point in time in order to describe the nature of existing conditions, or to identify standards against which the existing conditions can be compared, or to determine the relationships that exist between specific events (Cohen, Manion, \& Morrison, 2005). In this study, the data were collected from the participants once to determine the relationships between the variables that are within the scope of the study. Therefore, survey research design was found appropriate for this study.

\section{Participants}

The participants consisted of 776 students studying in the field of education (256 males and 520 females). Convenience sampling was used to gather data from the participants during course hours. The researchers explained the goals and scope of the study, and asked the pre-service teachers to participate in the survey. The volunteers filled in the survey questionnaires and returned them to the researchers. 70 participants were 19 years old or younger; 191 were 20 years old; 205 were 21 years old; 192 were 22 years old; 67 were 23 years old; 31 were 24 years old; and 20 were 25 years old or older. They were studying in different departments including Psychological Counseling and Guidance (203), Primary School Teaching (228), Social Sciences Teaching (103), Turkish Teaching (90), Science Teaching (80), and Computer Education and Instructional Technologies (72). 198, 257, and 321 students were in their second, third, and fourth year, respectively.

\section{Data Collection Tools}

The data for this study were gathered using three measures; the Academic Self-Efficacy Scale, the Academic Motivation Scale, and the Autonomous Learning Scale.

The Academic Self-Efficacy Scale (Jerusalem \& Schwarzer, 1981) was adapted into Turkish by Yılmaz, Gürçay, and Ekici (2007). The scale is composed of 7 items rated on a 4-point Likert scale, with higher scores indicating greater levels of academic self-efficacy. One of the 7 items is negatively worded. The alpha coefficient for the original scale was .87 (Jerusalem \& Schwarzer, 1981), while it 
was found to be .83 in the adaptation process (Yilmaz et al., 2007). In the present study, it was determined as .72.

The Academic Motivation Scale was developed by Vallerand et al. (1992) to determine the internal, external or amotivation levels of students, and has been adapted into Turkish by Karagüven (2012). The scale is composed of 28 items with 7 subscales -3 subscales each measuring Internal Motivation and External Motivation, and 1 subscale measuring Amotivation. Items are rated on a 7-point Likert scale. The scores obtained from the subscales are used to estimate the self-determination index, which indicates the academic motivation level of participants (Guay, Mageau, \& Vallerand, 2003). In the current study, the alpha coefficient of this scale was found to be .86 . The Autonomous Learning Scale was originally developed and validated by Macaskill and Taylor (2010) to determine the autonomous learning of individuals. The scale is composed of 12 items with 2 subscales assessing Independence of Learning and Study Habits. Items are rated on a 5-point Likert scale from 1 (not at all like me) to 5 (very like me), with higher scores indicating greater levels of autonomy, more independence and more positive attitudes towards learning. Two items were negatively worded to address response bias. The alpha coefficient was .78 for the complete scale, .73 for the Independence of Learning subscale and .76 for the Study Habits subscale.

The Autonomous Learning Scale was adapted into Turkish for the present study. The translation process involved translation, synthesis of translations, evaluation by a committee of experts and evaluation by the target audience, as recommended by Borsa, Damásio and Bandeira (2012). Following the translation process, the Turkish version of the Autonomous Learning Scale was administered to 335 pre-service teachers who were not participants of the main study. Confirmatory Factor Analysis (CFA) was conducted to test how well the obtained data fit the original structure of the scale. As a result of the analysis, $\chi^{2}(53)=142.02, p<.05$ was found. The other indexes were $\chi^{2} / \mathrm{df}=2.68, \mathrm{CFI}=.92, \mathrm{RMSEA}=.07, \mathrm{RMR}=.06$, GFI $=.93$, and $\mathrm{AGFI}=.90$. The findings showed a good fit of the data to the model (Kline, 2016). The original and Turkish versions of the scale can be seen in the Appendix. The standardized values and t-values of the items are shown in Figure 1. 


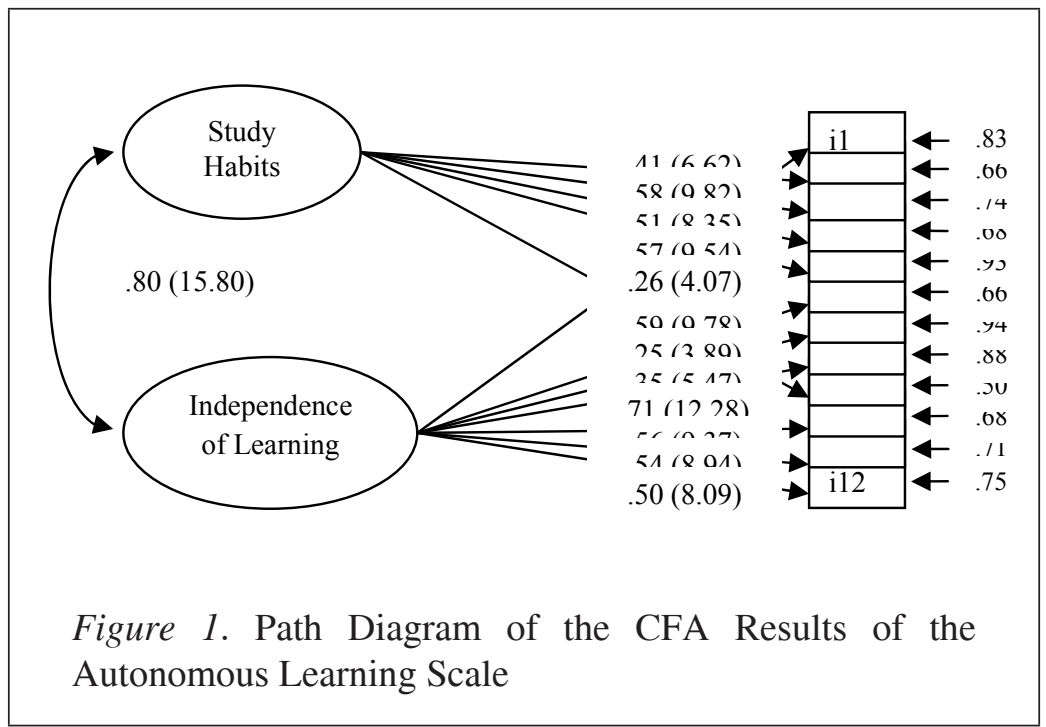

Note. $\mathrm{t}$-values are presented in parentheses.

As seen in Figure 1, the standardized values ranged from .25 to .71. The examination of t-values indicated that all of the items had significant loadings since the t-values were higher than the critical value of 2.56, which was determined at 0.01 significance level. These results showed that each item represented its factor well and the construct of the scale was validated.

\section{Data Analysis}

Multiple regression analysis, one-way variance analysis (ANOVA), independent samples t-test and correlation analysis were conducted using SPSS® software. The alpha value was set as .05.

\section{FINDINGS}

Firstly, descriptive statistics of the scores obtained from the three scales were estimated. These statistics can be seen in Table 1.

One-way variance analysis was conducted to determine whether the scores from the Autonomous Learning Scale differed significantly in terms of participants' age group, grade level, department, residential location, geographical region, type of high school and family income. The results showed that the learner autonomy levels of the participants did not differ significantly on any of these variables 
except for department and the type of high school from which the participants had graduated. The results can be seen in Table 2 .

Table 1

\section{Descriptive Statistics}

\begin{tabular}{lcccccc}
\hline & Mean & Sd & Min & Max & Kurtosis & Skewness \\
\hline $\begin{array}{l}\text { Autonomous } \\
\text { Learning }\end{array}$ & 44.18 & 6.23 & 25 & 60 & .08 & -.26 \\
$\begin{array}{l}\text { Academic Self- } \\
\text { Efficacy }\end{array}$ & 20.35 & 3.28 & 10 & 28 & -.13 & -.12 \\
$\begin{array}{l}\text { Self } \\
\text { Determination }\end{array}$ & 5.22 & 3.20 & -.6 .42 & 12.17 & -.23 & -.36 \\
Index & & & & & & \\
\hline
\end{tabular}

Table 2

One-Way Variance Analysis Results of Participants' Autonomous Learning Levels by Department and High School Type

\begin{tabular}{lrrrrr}
\hline Department & $\mathrm{N}$ & $\bar{X}$ & $\mathrm{Sd}$ & $\mathrm{F}$ & $\mathrm{p}$ \\
\hline Computer Education & 72 & 43.44 & 5.55 & & \\
Science Teaching & 80 & 44.37 & 6.16 & & \\
Primary School Teaching & 228 & 44.52 & 6.09 & & \\
Turkish Teaching & 90 & 45.56 & 5.56 & 4.087 & $.001^{*}$ \\
Social Sciences & 103 & 45.36 & 6.38 & & \\
Psychological Counselling & 203 & 42.79 & 6.58 & & \\
and Guidance & & & & & \\
Total & 776 & 44.18 & 6.23 & & \\
\hline High School Type & & & & & \\
Anatolian and Science HS & 195 & 43.56 & 6.05 & & \\
General HS & 417 & 44.82 & 6.30 & & \\
Teacher Training HS & 48 & 40.89 & 6.19 & & \\
Vocational-Technical HS & 89 & 44.17 & 5.96 & & \\
Other & 27 & 44.70 & 5.29 & & \\
Total & 776 & 44.18 & 6.23 & & \\
\hline
\end{tabular}

"p<.05 
There was a statistically significant difference between participants from different departments as determined by one-way ANOVA $(\mathrm{F}(5,770)=4.087, \mathrm{p}=.001)$. Post hoc comparisons using the Tukey HSD test indicated that the mean scores of the participants studying primary school teaching $(\mathrm{M}=44.52, \mathrm{SD}=6.09)$, Turkish teaching $(\mathrm{M}=45.56, \mathrm{SD}=5.56)$ and social sciences teaching $(\mathrm{M}=45.36$, $\mathrm{SD}=6.38$ ) were significantly different from the mean score of participants studying psychological counselling and guidance (M $=42.79, \mathrm{SD}=6.58)$. Table 2 also shows a statistically significant difference between participants who graduated from different types of high schools as determined by one-way ANOVA $(\mathrm{F}(4,771)=$ $5.072, \mathrm{p}=.000)$. Post hoc comparisons using the Tukey HSD test indicated that the mean scores of the participants who graduated from general high schools $(\mathrm{M}=44.82, \mathrm{SD}=6.30)$ and vocationaltechnical high schools $(\mathrm{M}=44.17, \mathrm{SD}=5.96)$ were significantly different from the mean score of the participants who graduated from teacher training high schools $(M=40.89, S D=6.17)$.

An independent samples t-test was conducted to determine whether the scores obtained on the Autonomous Learning Scale differed significantly in terms of gender.

Table 3

T-Test Results of Participants' Autonomous Learning Levels by Gender

\begin{tabular}{llrrrrrr}
\hline & Gender & $\mathrm{n}$ & $\bar{X}$ & $\mathrm{sd}$ & $\mathrm{df}$ & $\mathrm{t}$ & $\mathrm{p}$ \\
\hline Autonomous & Male & 256 & 43.26 & 6.41 & & & \\
Learning & Female & 520 & 44.64 & 6.09 & & 2.90 & $.004^{*}$ \\
\hline
\end{tabular}

${ }^{*} p<.05$

As seen in Table 3, there was a significant difference between the scores of male $(\mathrm{M}=43.26, \mathrm{SD}=6.41)$ and female students $(\mathrm{M}=44.64$, $\mathrm{SD}=6.09) ; \mathrm{t}(774)=2.90, \mathrm{p}=0.004$. Female students had significantly higher learner autonomy levels compared to male students.

The final variable was the participants' GPAs. Pearson productmoment correlation coefficients analysis revealed a significant positive correlation between learner autonomy and GPAs ( $\mathrm{r}=.176$, $\mathrm{p}<.05$ ). Although correlation does not yield a causal relationship, it 
can be stated that an increase in one of these variables will probably result in an increase in the other.

Before conducting hierarchical multiple regression, the assumptions of this analysis were tested. First, the assumption of singularity was met since the independent variables (Academic Self-Efficacy, Academic Motivation) were not a combination of other independent variables. The examination of correlations (see Table 4) revealed that there was no high correlation between the independent variables. Therefore, the assumption of multicollinearity was met. Residual and scatter plots indicated that the assumptions of normality, linearity and homoscedasticity were all satisfied (Hair, Anderson, Tatham, \& Black, 1998).

Table 4

Pearson Product-Moment Correlation Coefficients between Variables

\begin{tabular}{lccc} 
& Autonomous Learning & Self-Efficacy & Motivation \\
\hline $\begin{array}{l}\text { Autonomous } \\
\text { Learning }\end{array}$ & - & & \\
Self-Efficacy & $.481^{*}$ & - & \\
Motivation & $.450^{*}$ & $.238^{*}$ & - \\
\hline
\end{tabular}

$\mathrm{N}=776,{ }^{*} p<.05$

As indicated in Table 4, there was a significant positive correlation between learner autonomy and self-efficacy $(\mathrm{r}=.481, \mathrm{p}<.01)$ and motivation $(\mathrm{r}=.450, \mathrm{p}<.01)$. Moreover, although there was a significant and positive correlation between self-efficacy and motivation $(\mathrm{r}=.238, \mathrm{p}<.01)$, it was not high. Therefore, the assumption of multicollinearity was met.

A hierarchical multiple regression was conducted in order to explore the relationships between the predictors (academic self-efficacy and academic motivation) and the dependent variable (autonomous learning). Self-efficacy was entered at stage one of the regression because it had a higher correlation with autonomous learning higher than motivation. Motivation was entered at stage two. The regression statistics are given in Table 5 . 
Table 5

Summary of Hierarchical Regression Analysis for Variables Predicting Autonomous Learning

\begin{tabular}{lccccccccc}
\hline Variable & $B$ & $S E B$ & $\beta$ & $t$ & $p$ & $R^{2}$ & $\Delta R^{2}$ & $F$ & $p$ \\
\hline Self-Efficacy & .91 & .06 & .48 & 15.27 & $.00^{*}$ & .232 & .232 & 233.27 & $.00^{*}$ \\
\hline Self-Efficacy & .75 & .05 & .39 & 13.28 & $.00^{*}$ & & & & \\
Motivation & .69 & .05 & .35 & 11.92 & $.00^{*}$ & & & & \\
\hline $\mathrm{N}=776,{ }^{*} p<.05$ & & & & & & & & &
\end{tabular}

The hierarchical multiple regression revealed that at stage one, self-efficacy contributed significantly to the regression model, $\mathrm{F}$ $(1,774)=233.274, \mathrm{p}<.00$, and accounted for $23.2 \%$ of the variation in autonomous learning. Introducing motivation explained an additional $11.9 \%$ of variation in autonomous learning and this change in $\mathrm{R}^{2}$ was significant, $\mathrm{F}(2,77)=209.002, \mathrm{p}<.00$. Together, the two independent variables accounted for $35.1 \%$ of the variance in autonomous learning.

\section{DISCUSSION AND CONCLUSION}

Firstly, the Autonomous Learning Scale was adapted into Turkish in order to provide a valid and reliable data collection tool in the Turkish language. The fit indices showed that the Turkish version of the scale could be used with Turkish participants. Thus, this is an important outcome of this study.

As suggested by Social Learning Theory, the environment and the relationship individuals have with it have a significant role in their development and growth (Bandura, 1995; 1997). For this reason, a number of demographic variables were included in the study. Although the majority of these did not yield significant results, they provided important insights. The autonomous learning levels of the participants did not differ significantly in terms of age and grade levels. This finding concurs with the results of other studies (Ng \& Confessore, 2015; O'Reilly, 2014) and demonstrates that autonomous learning is independent of age. It suggests that experts, 
researchers, or teachers should carry out activities to increase the autonomous learning of individuals at all levels of education, at any age. In other words, activities aiming to increase the autonomous learning of individuals can be conducted with a wide range of school levels from primary school to higher education.

The participants were asked where they had spent most of their lives, whether in urban or rural areas. They were also asked to provide their family income and the geographical region of their home. The rationale behind these questions was the possible differences in the opportunities and affordances for autonomous learning among urban or rural locations or different income levels. However, the analyses did not yield significant differences in terms of these variables. This could be due to the nature of autonomous learning itself, because having higher levels of autonomy is related to decisiveness in taking one's own learning responsibility rather than being afforded with opportunities due to living in a rural or urban area. Although it seems natural to think that some characteristics will become higher or stronger if the opportunity to develop them is given, this might not always be the case. The ideas put forward by Billett (2014) relating to people's choices of making use of or denying the affordances provided by workplaces within the context of his workplace learning theory are also applicable to the results of this study. According to him, the basis by which individuals elect to engage with what is afforded to them is much more important than the actual affordances and opportunities provided. Even the most welcoming affordances might be rejected by individuals who are uninterested in engaging with what is being afforded. On the other hand, highly active and engaged individuals may be able to overcome the limitations of low affordances (Billett, 2001). In a similar manner, despite the importance and contributions of the environment, it is the decisions and choices of individuals that determine their autonomous learning levels. On the other hand, in a study conducted on older Malaysians, $\mathrm{Ng}$ and Confessore (2015) determined that the autonomous learning levels of older people living in urban areas were significantly higher than those living in rural areas, which in part contradicts with the results of the present study. In conclusion, independent from the places where individuals live and their income, autonomous learning can be increased by implementing appropriate activities and giving them responsibility for their own learning. 
The autonomous learning levels of the participants differed significantly according to their departments of study and the types of high schools from which they graduated. Firstly, the scores of students studying psychological counselling and guidance were significantly lower than various other departments. This result is interesting because the students with the highest scores obtained from university examinations are from this department. In other words, the most successful students in the faculty had the lowest autonomous learning scores. This may be explained by the features of the Turkish educational system. In Turkey, success equals getting high scores on exams by learning the knowledge given in accordance with the curriculum. Students only learn what schools or private institutions provide them (Sekin, 2008; Yılmaz \& Altınkurt, 2011). Characteristics related to learner autonomy are not among the elements that are especially rewarded at school. Therefore, this may prevent the development of learner autonomy. Secondly, the scores of the participants differed significantly according to types of high school. Those who graduated from teacher training high schools had significantly lower scores than those who graduated from other types of school. This finding is similar in nature to the finding regarding the department variable. Teacher training high schools accept students who achieve a higher score on the high school entrance exam compared with most other high school types. Therefore, the rote-learning system of Turkish education seems to be the source of the problem. Students are successful in their lessons but have lower learner autonomy.

Gender is the final demographic variable. The autonomous learning scores of the participants differed significantly in terms of gender. T-test results showed that female students had higher scores than male students. Some studies (Deregözü \& Hatipoğlu, 2018; Hanbay, 2013; Naeghel \& Keer, 2013; Razeq, 2014) support this finding while others (O'Reilly, 2014; Pan \& Gauvain, 2012) have not determined any significant difference. However, no study reporting a significant difference in favour of male students has been encountered in the literature. The scores of male students have been either equal to or lower than the scores of female students. In traditional Turkish families, boys are approached a little differently from girls. As boys have more freedom of choice, girls remain under the pressure of the family. The protective attitudes of families towards girls might have an effect on their higher learning autonomy because they have 
to put in more effort to achieve the things that are easily afforded to boys. Moreover, girls are given many responsibilities from an early age, such as the care of siblings and housework. This responsibility might be another factor leading to higher autonomous learning levels. Further research may reveal socio-cultural factors that have contributed to this situation.

Academic achievement was found to be associated with learner autonomy in a number of studies (Liu, 2007; Lowe, 2009; Ng et al., 2011). This relationship was also confirmed in the present study. The GPAs of the participants positively correlated with their autonomous learning levels, which was an expected and significant result. This finding has perhaps the most important implication. The positive relationship between autonomous learning and academic achievement suggests that from the early grade levels, increasing the learner autonomy of students will possibly increase their academic achievement. Therefore, even at the primary level, the implementation of activities and interventions aiming at learner autonomy are recommended. Policymakers and teachers should consider this relationship and integrate these kinds of activities into their curricula.

The relationships between autonomous learning and self-efficacy along with motivation, which have been asserted in a number of studies (Flannagan, 2007; Pu, 2009; Tılfarlıŏlu \& Çiftçi, 2011), were confirmed in the present study. This study not only corroborated the correlations among these variables, but also revealed their predictive power on autonomous learning. Earlier, it was recommended that the autonomous learning levels of students should be increased. Based on these findings, it can be said that increasing the self-efficacy and motivation of learners will probably result in an increase in their learner autonomy. Therefore, this relationship might offer a way to increase autonomous learning. A number of researchers have investigated ways to increase the learner autonomy of students (Macaskill \& Denovan, 2013; Kim, 2014; Lee, 2016; Petra, Jaidin, Perera, \& Linn, 2016; Varutharaju \& Ratnavadivel, 2014). Activities increasing motivation and self-efficacy in a classroom environment will be beneficial for the autonomy development of learners. Today, motivation and self-efficacy are two valuable characteristics in a classroom environment. This study confirmed their importance. Moreover, Kaur, Hashim and Noman (2014) showed that autonomy- 
supportive teaching-learning environments increased the interest, effort, relatedness, and integrated regulation of students. Similarly, Hang, Kaur, and Nur (2017) found that autonomy support from teachers predicted the motivation of college students significantly. These findings might indicate the reciprocal relationship between autonomy and motivation. Therefore, it is recommended that researchers should investigate the possible reciprocal relationship between these two variables.

In this study, the structural relations among learner autonomy, academic self-efficacy, and academic motivation were revealed using regression analysis. Although this analysis yields predictions instead of only correlations, an analysis using structural equation modelling (SEM) may be conducted with more variables extracted from the literature. SEM analysis should yield better results since it allows simultaneous analysis of the variables in the model instead of separately, as in regression analysis.

Today's teachers are expected to act autonomously to structure their learning and keep up with systemic changes. However, autonomous learning is not a simple construct. It has associations with and impacts on a number of variables, many of which were beyond the scope of this study. Therefore, the final recommendation is for more research to be conducted on learner autonomy in order to reveal it from every aspect.

\section{ACKNOWLEDGEMENT}

This study received no specific grant from any funding agency in the public, commercial, or non-profit sectors.

\section{REFERENCES}

Bandura, A. (1995). Comments on the crusade against the causal efficacy of human thought. Journal of Behavior Therapy and Experimental Psychiatry, 26(3), 179-190.

Bandura, A. (1997). Self-efficacy: The exercise of control. New York: W H Freeman \& Company. 
Benson, P. (2001). Teaching and researching autonomy in language learning. England: Pearson Education.

Billett, S. (2001). Learning through work: Workplace affordances and individual engagement. Journal of Workplace Learning, 13, 209-214.

Billett, S. (2014). Securing intersubjectivity through interprofessional workplace learning experiences. Journal of Interprofessional Care, 28(3), 206-211.

Borsa, J. C., Damásio, B. F., \& Bandeira, D. R. (2012). Cross-cultural adaptation and validation of psychological instruments: Some considerations. Paidéia (Ribeirão Preto), 22(53), 423-432.

Chalupa, C., \& Haseborg, H. T. (2014). Improving student motivation through autonomous learning choices. NECTFL Review, 74, 53-85.

Cohen, L., Manion, L., \& Morrison, K. (2005). Research methods in education (5th ed.). USA: Taylor \& Francis.

Deci, E., \& Ryan, R. (1985). Instrict motivation and selfdetermination in human behavior. New York: Plenum.

Deci, E., \& Ryan, R. (2008). Self-determination theory: A macrotheory of human motivation, development, and health. Canadian Psychology, 49(3), 182-185.

Deci, E., \& Ryan, R. (2002). Handbook of self-determination research. New York: The University of Rochester Press.

Deregözü, A., \& Hatipoğlu, S. (2018). An investigation on prospective German language teachers' autonomous learning level. Journal of Language and Linguistic Studies, 14(1), $1-10$.

Dickinson, L. (1995). Autonomy and motivation: A literature review. System, 23(2), 165-174.

Flannagan, J. S. (2007). A study of student achievement based on autonomous learning and self-efficacy (Unpublished doctoral dissertation). Regent University, USA.

Garcia, T., \& Pintrich, P. (1996). The effects of autonomy on motivation and performance in the college classroom. Contemporary Educational Psychology, 21, 477-486.

Guay, F., Mageau, G., \& Vallerand, R. (2003). On the hierarchical structure of self-determined motivation: A test of top-down, bottom-up, reciprocal, and horizontal effects. Personality and Social Psychology Bulletin, 29, 992-1004.

Hair, J. F., Anderson, R. E., Tatham, R. L., \& Black, W. C. (1998). Multivariate data analysis. New York: Macmillan. 
Hanbay, O. (2013). Anadolu lisesi öğrencilerinin cinsiyet değişkenine göre ikinci yabancı dil olarak almanca dersinde bağımsız öğrenme düzeyleri. [The autonomous learning level of the Anatolian high school students in German as a second foreign language]. Uşak Üniversitesi Sosyal Bilimler Dergisi, 6(4), 271-280.

Hang, B. T. T., Kaur, A., \& Nur, A. H. B. (2017). A self-determination theory based motivational model on intentions to drop out of vocational schools in Vietnam. Malaysian Journal of Learning and Instruction, 14(1), 1-21.

Holec, H. (1981). Autonomy in foreign language learning. Oxford: Pergamon.

Jerusalem, M., \& Schwarzer, R. (1981). Fragebogen zur erfassung von selbstwirksamkeit. skalen zur befindlichkeit und persoenlichkeit. [Questionnaire for the assessment of selfefficacy. Scales to the condition and personality]. Berlin: Freie Universitaet.

Kaplan, A. (2016). Lifelong learning: Conclusions from a literature review. International Online Journal of Primary Education, 5(2), 43-50.

Karagüven, M. H. (2012). Akademik motivasyon ölçeğinin türkçeye adaptasyonu. [The adaptation of academic motivation scale to Turkish]. Kuram ve Uygulamada Eğitim Bilimleri, 12(4), 2599-2620.

Kaur, A., Hashim, R. A., \& Noman, M. (2014). Teacher autonomy support: Does it hinder motivation among Thai students? Malaysian Journal of Learning and Instruction, 11, 171-189.

Kim, S. (2014). Developing autonomous learning for oral proficiency using digital storytelling. Language Learning \& Technology, 18(2), 20-35.

Kline, R. B. (2016). Principles and practice of structural equation modelling ( $4^{\text {th }}$ ed.). New York: Guilford Publications.

Lee, L. (2016). Autonomous learning through task-based instruction in fully online language courses. Language Learning \& Technology, 20(2), 81-97.

Liu, J. (2007). Learner autonomy and Chinese university students' English profictency: A quantitative and qualitatıve study (Unpublished doctoral dissertation). Regent University, USA.

Lowe, C. (2009). A correlational study of the relationship between learner autonomy and academic performance (Unpublished doctoral dissertation). George Washington University.USA . 
Macaskill, A., \& Denovan, A. (2013). Developing autonomous learning in first-year university students using perspectives from positive psychology. Studies in Higher Education, 38(1), 124-142.

Macaskill, A., \& Taylor, E. (2010). The development of a brief measure of learner autonomy in university students. Studies in Higher Education, 35(3), 351-359.

Mahmoudi, H., \& Asadi, M. (2016). The relationship among autonomy, self-efficacy, and critical thinking of Iranian upper-intermediate EFL learners. Language Education Studies, 2(2), 16-25.

Medel-Anonuevo, C. (2002). UNESCO. Retrieved from www. unesco.org/education/uie/pdf/uiestud36.pdf - Fransa

Mynard, J., \& Sorflaten, R. (2003). Independent learning in your classroom. Teachers, Learners and Curriculum Journal, 1, 34-38.

Naeghel, J. D., \& Keer, H. V. (2013). The relation of student and class-level characteristics to primary school students' autonomous reading motivation: A multi-level approach. Journal of Research in Reading, 36(4), 351-370.

$\mathrm{Ng}$, S. F., \& Confessore, G. J. (2015). Learner autonomy and selected demographic characteristics as they relate to life satisfaction among older adults in Malaysia. Educational Gerontology, $41,361-372$.

Ng, S. F., Confessore, G. J., Yusoff, Z., Aziz, N. A., \& Lajis, N. M. (2011). Learner autonomy and academic performance among undergraduate students. International Journal of Social Sciences and Education, 1(4), 669-679.

Niemiec, C. P., \& Ryan, R. M. (2009). Autonomy, competence, and relatedness in the classroom: Applying self-determination theory to educational practice. Theory and Research in Education, 7(2), 133-144.

Nosratinia, M., \& Hossaini, F. A. (2018). Self-efficacy and critical thinking as the predictors of autonomous language learning in EFL contexts. International Journal of Applied Linguistics \& English Literature, 7(1), 64-72.

O’Reilly, E. N. (2014). Correlations among perceived autonomy support, intrinsic motivation, and learning outcomes in an intensive foreign language program. Theory and Practice in Language Studies, 4(7), 1313-1318. 
Overall, N., Deane, K., \& Peterson, E. (2011). Promoting doctoral students' research self-efficacy: Combining academic guidance with autonomy support. Higher Education Research and Development, 30(6), 791-805.

Oxford, R. (2003). Toward a more systematic model of L2 learner autonomy. In In D. Palfreyman, and R. Smith (Eds.), Learner autonomy across cultures: Language education perspectives (p. 75-91). Great Britain: Palgrave McMillian.

Pan, Y., \& Gauvain, M. (2012). The continuity of college students' autonomous learning motivation and its predictors: A threeyear longitudinal study. Learning and Individual Differences, 22, 92-99.

Petra, S. F., Jaidin, J. H., Perera, Q., \& Linn, M. (2016). Supporting students to become autonomous learners: The role of webbased learning. International Journal of Information and Learning Technology, 33(4), 263-275.

Ponton, M., Derrick, M. G., Confessore, G., \& Rhea, N. (2005). The role of self-efficacy in autonomous learning. International Journal of Self-Directed Learning, 2(2), 81-90.

$\mathrm{Pu}, \mathrm{M}$. (2009). An investigation of the relationship between college Chinese EFL students' autonomous learning capacity and motivation in using computer-assisted language learning. (Unpublished doctoral dissertation). University of Kansas, USA.

Razeq, A. A. (2014). University EFL learners' perceptions of their autonomous learning responsibilities and abilities. RELC Journal, 45(3), $321-336$.

Ryan, R., \& Deci, E. (2000). Intrinsic and extrinsic motivations: Classic definitions and new directions. Contemporary Educational Psychology, 54-67.

Sekin, S. (2008). Reasons of rote learning in Turkey. Marmara Coğrafya Dergisi, 18, 211-221.

Spratt, M., Humphreys, G., \& Chan, V. (2002). Autonomy and motivation: Which comes first? Language Teaching Research, 6(3), 245-266.

Tılfarlıoğlu, F. Y., \& Çiftçi, F. Ş. (2011). Supporting self-efficacy and learner autonomy in relation to academic success in EFL classrooms (A case study). Theory and Practice in Language Studies, 1(10), 1284-1294.

Vallerand, R., Pelletier, L., Blais, M., Breire, N., Senecal, C., \& Vallieres, E. (1992). The academic motivation scale: A measure of intrinsic, extrinsic, and a motivation in education. Educational and Psychological Measurement, 52, 1003-1017. 
Varutharaju, E., \& Ratnavadivel, N. (2014) Enhancing higher order thinking skills through clinical simulation. Malaysian Journal of Learning and Instruction, 11, 75-100.

Yılmaz, K., \& Altınkurt, Y.(2011). Prospective teachers' views about the problems of Turkish educational system. Uluslararast Insan Bilimleri Dergisi, 8(1), 942-973. Yılmaz, M., Gürçay, D., \& Ekici, G. (2007). Akademik özyeterlik ölçeğinin Türkçeye uyarlanması. [Adaptation of academic self-efficacy scale into Turkish]. Hacettepe Üniversitesi Ĕ̈itim Fakültesi Dergisi, 33, 253-259. 


\section{APPENDIX}

\section{The Original and Translated Versions of the Items on the Autonomous Learning Scale}

\section{Which of the following best describes you?}

1

Not at all

like me
3

Neither like or unlike me
4

Quite

like me
5

Very

Original Items

Items in Turkish

\begin{tabular}{|c|c|c|c|c|c|c|}
\hline $\begin{array}{l}\text { I enjoy finding } \\
\text { information about new } \\
\text { topics on my own }\end{array}$ & $\begin{array}{l}\text { Kendi kendime yeni konularla ilgili } \\
\text { bilgiler bulmaktan zevk alırım. }\end{array}$ & 1 & 2 & 3 & 4 & 5 \\
\hline $\begin{array}{l}\text { I frequently find } \\
\text { excuses for not getting } \\
\text { down to work. }\end{array}$ & $\begin{array}{l}\text { Bir ödeve başlamamak için sıklıkla } \\
\text { bahane bulurum. }\end{array}$ & 1 & 2 & 3 & 4 & 5 \\
\hline $\begin{array}{l}\text { I am good at meeting } \\
\text { deadlines. }\end{array}$ & $\begin{array}{l}\text { Ödev teslim zamanlarına uyma } \\
\text { konusunda iyiyimdir. }\end{array}$ & 1 & 2 & 3 & 4 & 5 \\
\hline $\begin{array}{l}\text { My time management } \\
\text { is good. }\end{array}$ & Zaman yönetimim iyidir. & 1 & 2 & 3 & 4 & 5 \\
\hline $\begin{array}{l}\text { I am happy working on } \\
\text { my own. }\end{array}$ & $\begin{array}{l}\text { Kendi başıma çalışmaktan zevk } \\
\text { alırım. }\end{array}$ & 1 & 2 & 3 & 4 & 5 \\
\hline $\begin{array}{l}\text { Even when tasks are } \\
\text { difficult, I try to stick } \\
\text { with them. }\end{array}$ & $\begin{array}{l}\text { Ödevler zor olduğunda bile devam } \\
\text { edip bitirmeye çalışırım. }\end{array}$ & 1 & 2 & 3 & 4 & 5 \\
\hline $\begin{array}{l}\text { I am open to new } \\
\text { ways of doing familiar } \\
\text { things. }\end{array}$ & $\begin{array}{l}\text { Aynı şeyleri farklı yollarla yapmaya } \\
\text { açığımdır. }\end{array}$ & 1 & 2 & 3 & 4 & 5 \\
\hline $\begin{array}{l}\text { I enjoy being set a } \\
\text { challenge. }\end{array}$ & $\begin{array}{l}\text { Bana zor ödevler verilmesinden zevk } \\
\text { alırım. }\end{array}$ & 1 & 2 & 3 & 4 & 5 \\
\hline $\begin{array}{l}\text { I plan my time for } \\
\text { study effectively. }\end{array}$ & $\begin{array}{l}\text { Ders çalışmak için zamanımı etkili } \\
\text { bir şekilde planlarım. }\end{array}$ & 1 & 2 & 3 & 4 & 5 \\
\hline $\begin{array}{l}\text { I tend to be motivated } \\
\text { to work by assessment } \\
\text { deadlines. }\end{array}$ & $\begin{array}{l}\text { Sadece ödev teslim tarihleri } \\
\text { yaklaştığı zaman çalışmaya } \\
\text { güdülenirim. }\end{array}$ & 1 & 2 & 3 & 4 & 5 \\
\hline $\begin{array}{l}\text { I take responsibility } \\
\text { for my learning } \\
\text { experiences. }\end{array}$ & $\begin{array}{l}\text { Öğrenme deneyimlerimin } \\
\text { sorumluluğunu alırım. }\end{array}$ & 1 & 2 & 3 & 4 & 5 \\
\hline $\begin{array}{l}\text { I enjoy new learning } \\
\text { experiences. }\end{array}$ & $\begin{array}{l}\text { Yeni öğrenme deneyimlerinden zevk } \\
\text { alırım. }\end{array}$ & 1 & 2 & 3 & 4 & 5 \\
\hline
\end{tabular}

